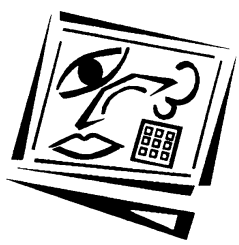

\title{
Using blogs to help language students to develop reflective learning strategies: Towards a pedagogical framework
}

\author{
Tríona Hourigan and Liam Murray \\ University of Limerick
}

\begin{abstract}
Due to the social changes brought about in no small part by Web 2.0 tools, the potential impact of the blog writing phenomenon upon teaching and learning contexts reveals an important area for consideration for all university educators, and in particular for e-learning practitioners. Today, web users may access a wide variety of media to express themselves and to communicate with others. These may include conventional blog websites such as blogger.com or indeed social networking sites such as MySpace, Facebook or Bebo, which continue to integrate blog tools and which also encourage self-expression on the part of the users. Moreover, the application of such written expression tools into a language learning context requires further investigation by the computer-assisted language learning (CALL) community, most notably in the field of exploring the distinct pedagogical environment which emerges within such a context. This paper shall detail the pedagogical and support role of the teacher as well as considering the content of learners' reflective output throughout the course of the semester. Our analysis will consider the overall teaching and learning environment, with additional qualitative examples from the learner blogs and essays in order to define clearly emerging roles and activities with regard to future classroom practice.
\end{abstract}

\section{Introducing blogging and CALL research}

Berners-Lee's original web weaving in 1990 is now generally accepted as a radical catalyst of self expression and global connectivity (Butler, 1998). Since then, additional upheavals have occurred: from search engines such as Altavista, Google, Cuil and Wolfram Alpha, to podcasting, RSS feeds and Twitter, to name but a few components of the Web 2.0 social software revolution. Uniquely bridging both these evolutions stands blogging. Blogging, as Hill states: "is throwing the Internet forward and backward at the same time. Forward into a new era of consumer empowerment, and backward to the grass-roots spirit of the early Web" (2006:19). As we shall see in this paper, the consumers are also the producers of content and if blogging for language learning (L2) purposes is to be both empowering and engaging, it must first be integrated efficaciously into current modern foreign language pedagogies. Indeed, the recent impact of Web 2.0 tools on education clearly represents important developments in terms of current pedagogical practice. The introduction of a wide range of such innovative new technologies into teaching and learning contexts underpins the necessity of reflecting upon their proposed role and contribution within this distinct environment. Examples of such Web 2.0 tools which have recently been evaluated as potential learning aids include: podcasts (Lonn and Teasley 2009; Walls et al., 2010); online games (Paraskeva, Mysirlaki \& Papagianni, 2010); smart phones (Cochrane \& 
Bateman, 2010); wikis (Elgort, Smith \& Toland, 2008; Zorko, 2009) and social networking sites (Vie, 2008; Lockyer \& Patterson, 2008).

While already established within recreational online activities, the main challenge in exploiting these tools lies in establishing clear contexts of use across different disciplines in higher education. Thus, while some Web 2.0 applications are already being used in academic institutions as valid alternative approaches to the teaching of computer science, mathematics and statistics (Alt, 2006), CALL practitioners and teachers have also been quick to appreciate, evaluate and integrate such applications (Godwin-Jones, 2003; 2005). Despite the increasing use of mobile technologies with its echoes of 'invisible' ubiquitous computing and mobile-assisted language learning (MALL) practices (Kukulska-Hulme \& Shield, 2008; Chinnery, 2006), many researchers continue to investigate the disruptive nature of technologies with their incumbent advantages and disadvantages (Heilesen \& Josephsen, 2007). It is clear therefore that we should revisit Hubbard's description of CALL as being "most properly viewed not as computers teaching people but as people teaching people through the medium of computers" (1996:32).

\section{Blogging as a learning activity}

Research on the potential of blogs for enhancing second language acquisition has been growing since the start of this century (Duber, 2002; Godwin-Jones, 2003), with blogging changing "the dynamic of teaching rhetorical sensitivity" (Will, 2005, July Entry section). Indeed, the medium of blogging is distinct from web page content management. Blogging software encourages frequent site updates with the content, or 'microcontent', as Alexander (2006:34) prefers to name it, being presented in reverse chronological order. Hence, the microcontent or posts are mainly composed of the blogger's own opinions and thoughts, showing why they are referred to as 'online diaries' (Wikipedia, 2008). Moreover, blogs can successfully promote self expression in a place where the L2 learner/blogger is developing deeply personalised content dealing with their language learning strategies (Murray \& Hourigan, 2008). Being both potentially individualistic and collaborative (Rourke and Coleman, 2009), blogs can transcend linguistic barriers and may be used for language learning purposes, where bloggers: "become part of a discourse community in a complex multimodal setting" (Raith, 2009:276), learning together in "collaborative spaces where people negotiate and construct meaning and texts" (Richardson, 2006:74).

Although researchers (Ducate \& Lomicka, 2005; Hendron, 2003; Murray \& Hourigan, 2005) have described and argued in favour of teachers adapting blog writing for all parties involved in the L2 and the cultural acquisition process, one must add a 'caveat' for teachers (and teacher developers) who are considering this process. Walinski (2005) describes an unsuccessful attempt to use blogs for feedback with ELT teachers in Poland who had been tasked with blogging about the integration and employment of e-learning methods in their teaching. Surprisingly, Walinski mentions no underlying theoretical perspective to this research and the integration timeframe is very short (2 weeks) with no attempt being made to address the participating teachers' fears and worries throughout the integration process. Despite Walinski's problematic methodology and rigid implementation, one definite and important caveat remains valid and relates to issues of blogger privacy and the appropriateness of the set tasks. Unsurprisingly, the main problems reported were the 'post-communist mindset' (reluctance to reveal private thoughts) and cultural practices with the teachers being 
obliged to continue to participate in the blogging despite the main task being of too personal a nature for the group (Walinski, 2005: 442).

Another caveat for teachers can be identified in a recent study by Strampel and Oliver (2008) who examined the reflective content produced by student bloggers in a university setting. Even though students in this cohort were encouraged to produce critically reflective blog postings, their highest levels of output typically fell under the categories of descriptive reflection and cognitive retrieval. This again highlights the necessity of investigating the quality of the learning experience established within the blogging environment in order to justify the potential bonus afforded by an alternative technological tool.

On the positive side, other researchers have described more successful attempts at integrating blogging for educational purposes, for improving L2 writing (Leja, 2007; Downes, 2004); for significantly increasing students' 'reflective learning processes' (Xie et al, 2008:18) and for developing an L2 community of writers (Sollars, 2007). Alm (2009) also highlights a number of additional advantages, discussing how using blogs in the classroom allowed a group of language students to control more readily their immediate environment, to personalise their own space and to engage in meaningful and relevant exchanges with their classmates. Furthermore, it is undeniable that "blogging requires higher-order thinking skills such as the ability to evaluate and synthesise" (Ford, 2007:9), therefore teacher and student roles should be clearly defined, in addition to "the complexities these sites showcase and what ramifications they may hold for our pedagogies and our field" (Vie, 2008: 23). In addition, Hsu and Lin (2008: 67) developed a model based on the theory of 'reasoned action' which involves "technology acceptance, knowledge sharing and social influences". Their project was effectively a group blog, strongly encouraging a single step approach in the use of the technology and the sharing of knowledge and discussion amongst student peers. This model uncovered the importance of "altruism and reputation" within their blogging context of 212 participants.

For our purposes, integrating blogware successfully into a classroom context means acknowledging the distinct set of tasks which emerge for both teacher and student in this environment. This is particularly crucial given the necessary steps which must be taken in order to adapt adequately to the blog writing task demands. Thus, following Kern's recommendation to "be prepared for new ways of structuring tasks" (2006:201) and Farmer, Yue and Brook's (2008) emphasis on introducing blogging as an integral component of the learning programme, we aim in this paper to outline clearly the particular activities inherent in our specific L2 blogging context. It is undeniable that there will be an inevitable blending of multimodal technologies on the web (Farmer, Yue \& Brook, 2008: 195), and we do recognise the huge importance of this movement in the direction of 'media integration on the Internet' (Carney, 2009: 306). However, it may be stated that blogs continue to maintain their distinct 'presence' on the web, for example note the increasing popularity of the "citizen bloggers" on so many national newspapers (e.g. Le Monde, The Australian, The Times of London, Time Magazine, The Guardian, The Irish Times). This 'presence' reveals the ongoing need for the space with Web 2.0 to express ourselves in a particular way. Regardless of the medium / media chosen for expression, as educators we still have the choice of designing the pedagogic task to oblige the learner to either speak / record / listen via podcasting; to record visually via videologs; or to type the well-considered word. 
After introducing the potential of using blogs for learning purposes, we shall now outline in more detail the methodological approach unique to this particular study.

\section{Methodology}

\subsection{Context and student profile}

This study details the blog integration process incorporating the activities of one teacher and a class of 45 students which took place from September to January during the 2007/ 2008 academic year. The students who participated in this study were second year MFL (Modern Foreign Language) students who had enrolled in the Language and Technology module at the authors' University. The aim of this specific module is to introduce students to the integration of ICT tools into their personalised learning strategies. Over a 12 week semester, students typically develop experience with using various software and resources such as: corpora, machine translation, automated summarisers, blogs, and both generic and dedicated language learning websites. In fact, this is the only course of its kind offered to MFL students at the university. The module was devised chiefly to introduce students to the major pedagogical, professional and research applications of technology in modern languages and to enable students to integrate these into their studies. Typically, students taking this module come from various degree courses such as Language and Cultural Studies, Applied Languages and the Erasmus Study Abroad program. The main languages on offer to these students include French, German, Spanish, Irish, Japanese and Teaching English as a Foreign Language. In terms of previous experience with ICT, all students had at least one form of online presence via a social networking site such as Bebo or Facebook. However, learners in this particular cohort would typically be inexperienced in terms of exploiting and reflecting on their use of technology for learning purposes.

Due to their familiarity with social media, as young people, students may in the past have been called "digital natives" (Prensky, 2001). However, our findings continue to show that they are not 'digital learning natives', in other words, they need to receive adequate and substantial tuition in exploiting ICT for learning purposes. Similar findings and questioning of Prensky's claims have been reported by Kennedy, Judd, Churchward, Gray and Krause (2008). Acknowledging that their report is limited to a study of the first year cohort of more than 2,000 students at an Australian university, the authors conclude: "It is difficult to expect students to have the expertise to judge how to best use emerging technologies for educational purposes" (Kennedy et al, 2008). In our context, before taking our particular module, learners would have followed more traditional modules on topics such as literature and grammar as part of their MFL course of study. As such, they would have not have registered on any formal course promoting the development of independent or generic ICT study skills. For a summary of the learners' profile at the commencement of the module, please refer to Table 1 and Figure 1.

Table 1: Breakdown of student-language combinations $(n=45)$

\begin{tabular}{|l|c|c|c|c|c|c|}
\hline $\begin{array}{c}\text { Main subject } \\
\text { below }\end{array}$ & French & German & Spanish & TEFL & Gaeilge & Japanese \\
\hline French with & - & 2 & 10 & 1 & 6 & 0 \\
\hline German with & 0 & - & 5 & 3 & 2 & 0 \\
\hline Spanish with & 0 & 0 & - & 10 & 1 & 0 \\
\hline TEFL with & 2 & 0 & 2 & - & 0 & 1 \\
\hline
\end{tabular}




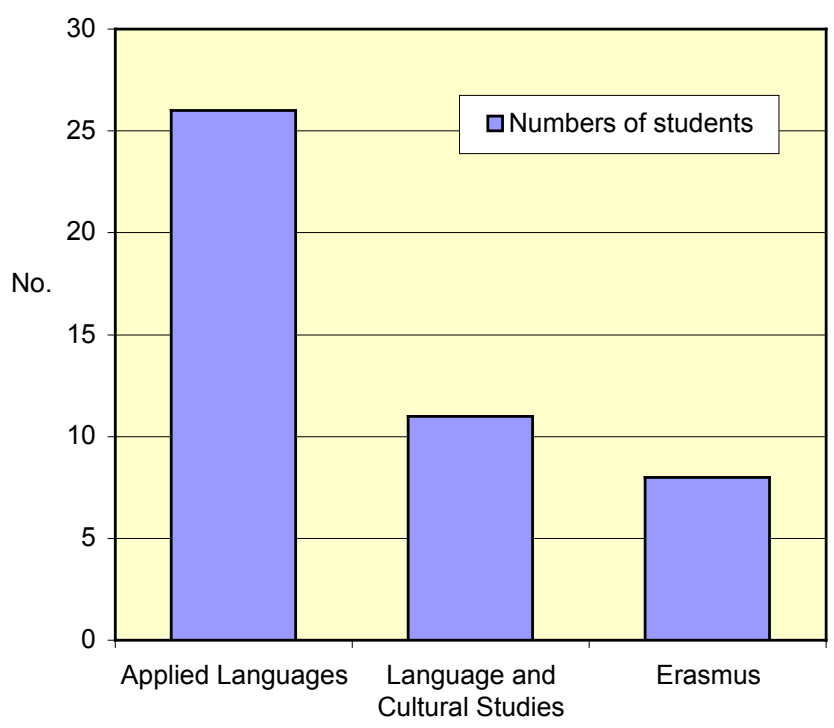

Figure 1: Enrolments by degree program $(n=45)$

\subsection{Design and integration of the reflective blogging task}

The reflective blog writing task was worth $20 \%$ of the overall mark for the Technology and Learning module. In addition, students were also required to complete two other projects worth $40 \%$ based on other aspects covered on the course. The blogging task required the students to undertake the following activities:

1. Consistent posting on their blog, detailing their various language learning strategies and experiences throughout the course of the semester;

2. Submission of a 1,000 word essay on their reflective experiences in relation to second language acquisition (SLA).

Frequent blog entries were required during the semester in order to allow students to become accustomed to using this writing space for L2 (second laguage learning) purposes. This decision was taken simply because we wanted to guide learners in their transition from the generic and oftentimes recreational blogosphere to this now specific language learning blogging space. Hence, it was important that students understood the significance of keeping their entries L2 focused and did not to fall into the trap of writing about non-SLA experiences. As such, this reflective task had to be completed over the 12 week period with at least two entries with a minimum of 100 words being posted per week by the learner. Students then used the content of their blog entries for a final essay reflecting upon the ways in which they exploited the blog and their feelings towards using this tool in their future and/or long term language learning. In terms of assessment, students were graded on structure and presentation of the essay, and elaboration and development of their main points. This was to ensure that they would embrace the expressivist nature of this particular technology integration task. In addition, the possibility of using the blog for interactive purposes with either fellow classmates or bloggers was also highlighted as an added bonus for the students. However, this interactive option was left to the learners' own discretion and was not included as a mandatory element of the assessment. 
Please refer to Figure 2 for a summary of this process. For more detail on this established expressivist blogging approach, please consult Murray and Hourigan $(2007 ; 2008)$.

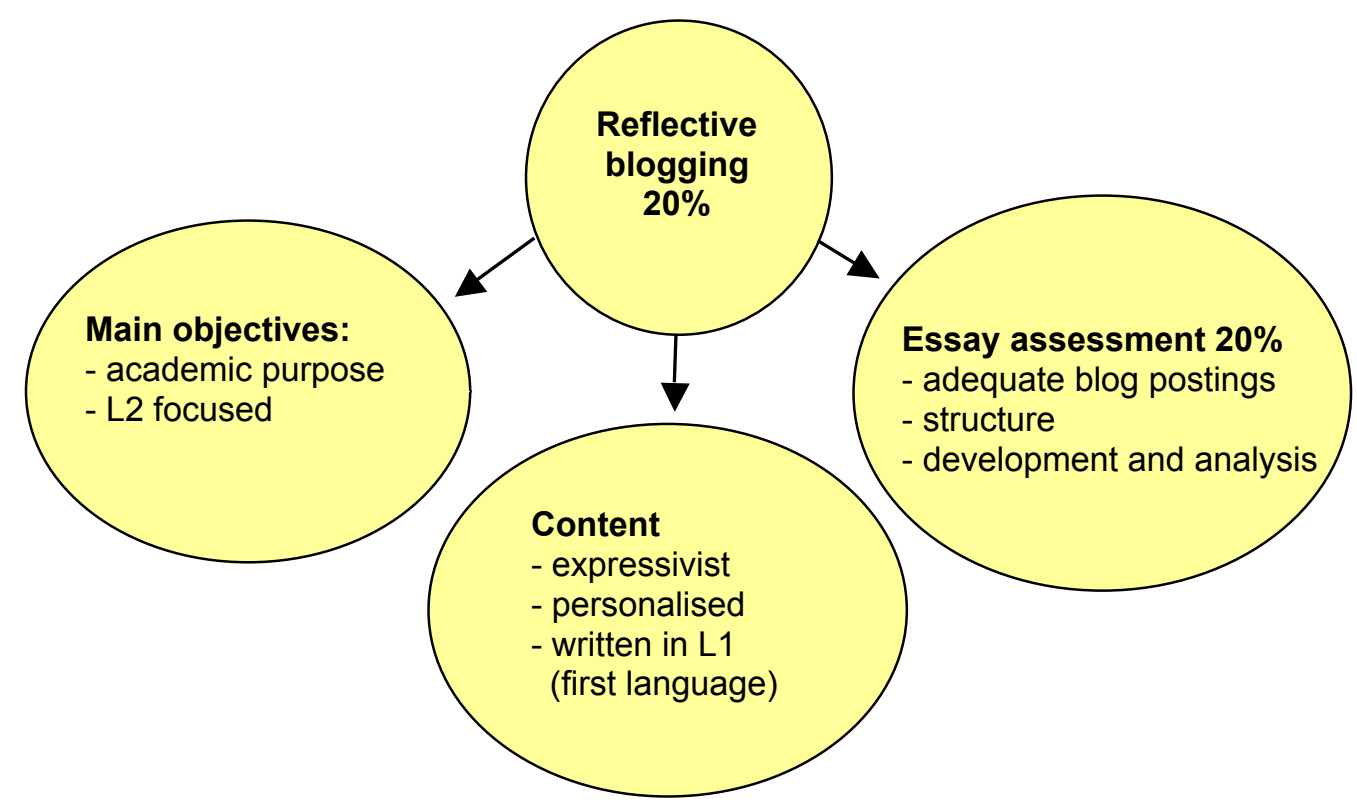

Figure 2: Establishing the reflective blogging task

This research study is part of ongoing action research over the last five years at the university regarding the development of an effective blog integration methodology. The discussion and analysis in this paper is based on qualitative data collated during this particular phase. Examples of personalised content of the learners' blogs and essays are examined in order to underline a number of salient themes emerging throughout the course of the semester. In addition, correspondence with the teacher as well as classroom observational notes is used to detail the distinct pedagogical context established.

\section{Creating a context for blogs: Preparative and ongoing teaching activities}

The process of integration itself is often viewed as a difficult and complex procedure to establish. Essentially, the context in which the actual learning takes place is regarded by many as being paramount to helping the teacher to implement realistic goals throughout the duration of the study. In many respects, there are a number of global variables, such as institutional vision, timetabling, access to PCs, departmental support - to mention but a few - which greatly influence how we may measure the outcomes of any ICT integration procedure. While previous studies established our expressivist assessment objectives (Murray \& Hourigan 2007; 2008) we wanted in this current phase to examine the characteristics of this specific process as it unfolded inductively throughout the semester. In Figure 3, the particular evolving teaching and learning structure details how certain environmental factors shaped the different types of activities undertaken by the teacher in this setting. Contextual input factors such as the 
design of the course and its learning objectives resulted in a number of specific responses on the part of the teacher. Face to face classroom teaching time was quite limited in this course, with the initial allocation of three formal teaching weeks (Weeks 2-4 of semester) comprising one lecture hour and two lab hours for this cohort of students. As such, a great deal of interaction outside of the formal classroom context was anticipated, especially with regard to queries by the students at different stages of the task during the semester. Consequently, these particular constraints resulted in additional administrative duties on the part of the teacher and were regarded as essential to enhance the integration experience for students. Grouping together

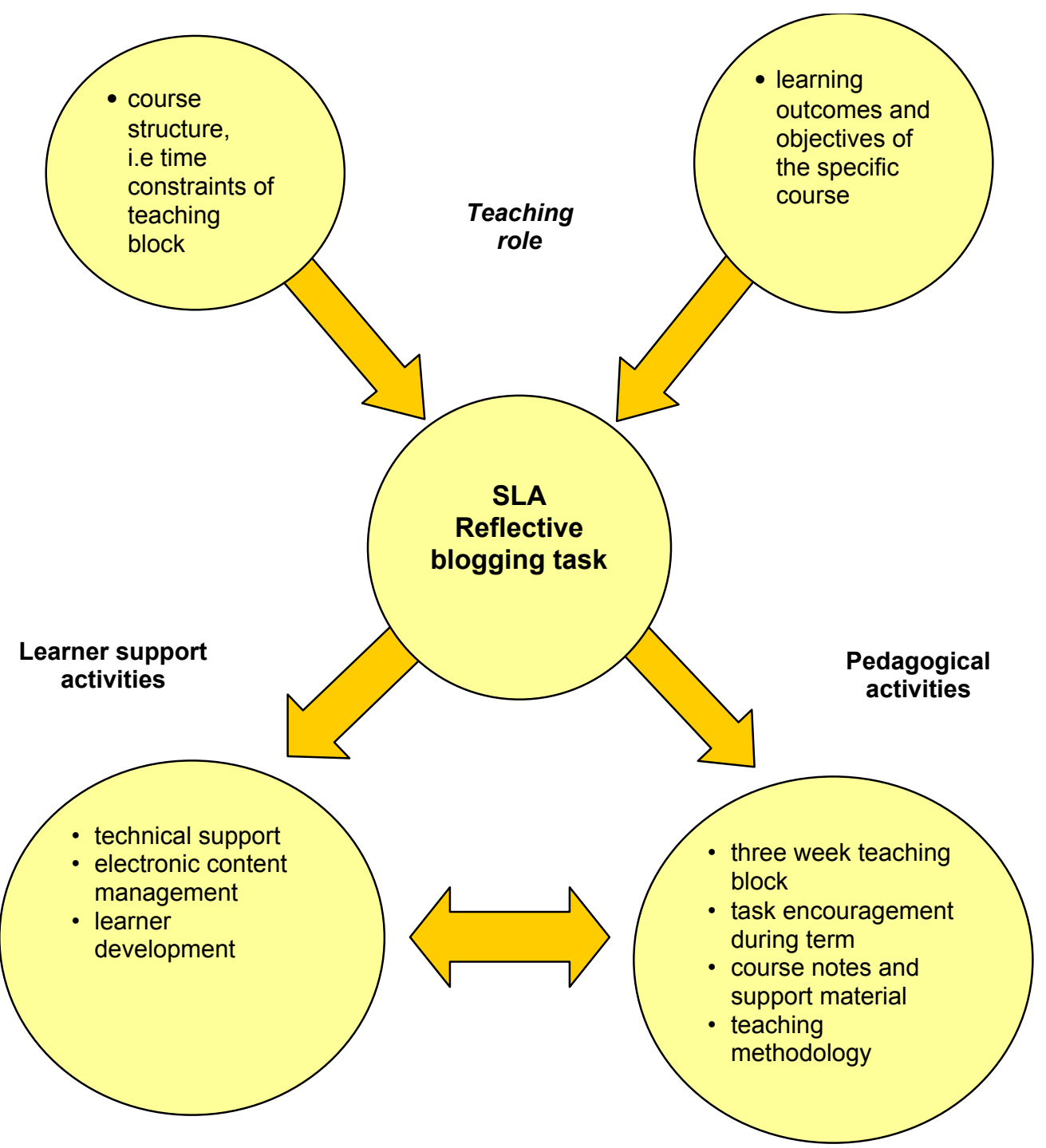

Contextual input pedagogical the specific .e time ints of eaching

\section{Contextual input \\ Contextual input
- organisational}

Figure 3: Description of teacher activities 
the different types of activities undertaken, we can identify two main categories which we shall examine in due course, namely learner support activities and pedagogical activities. Learner support activities emerged as the most time consuming of the tasks and thus shall be discussed in more detail. They can be divided into three primary areas, providing technical support, learner development, and electronic content management. Pedagogical activities centre around three main areas, task encouragement and reinforcement, provision of support material, and refining one's overall teaching methodology. We discuss a number of examples from these categories in order to highlight the significance of these roles within this blog integration context.

The question of technical support is a crucial consideration for any teacher thinking of introducing a new e-learning tool into the classroom. From our experience, this type of support is an essential and often time consuming requirement of the process. While students may indeed have an online social networking presence dedicated to their recreational activities, the appropriation of these or similar tools is often not so straightforward in nature within an academic context (Kennedy et al. 2008; MacLean \& Elwood, 2009). What became apparent from our study was the necessity to establish good organisational practice from the immediate outset, in order to be prepared adequately for the wide variety of email requests. Given the lack of contact hours, students submitted their work and assignments electronically to the teacher. Examples from student correspondence included the following:

- It seems that there is a problem with my XX account. All the e-mails that I had sent for the past few weeks hadn't been sent. This includes all my assignments.

- I "lost" the first one in cyberspace.

- It might help if I attached it.

- I only just realised that I sent you the wrong blog address.

The above correspond to the typical types of correspondence one may expect when using this particular submission method, such as attachment errors, poor backup practices and server problems. However, the main point to emphasise here is the importance of understanding and patience required of the teacher who did not have any formal face to face interaction with the students after the initial three week teaching block. Excluding the more predictable categories of technical problems, the actual establishment of the blog itself was a significant phase of the integration procedure, which brought its own set of questions to be addressed. We can identify a number of these emerging issues in the following examples:

- Can you give me the full address? The one below doesn't work.

- Below is the address for emailing you, can I have the address for reading the blog?

- Could I have the full address, please? Just the URL from the address line will suffice.

- Hi John, can you invite me again please? Thanks.

Firstly, students were asked to send on their blog addresses to the teacher at the start of semester which were subsequently compiled onto the teacher's blog database. The blog addresses then had to be checked that they were authentic and indeed active by the teacher. One subsequent problem stemming from these activities was that many students confused their login name with the actual URL of their blog, resulting in additional email correspondence in order to resolve the issue. Unsurprisingly, access to public blogs was never a problem; however students wishing to make their blogs private for the semester resulted in the fact that many viewing invitations became invalid. Consequently, it was necessary to check that the invitation period had not 
expired at different points of the semester and to remind learners to either extend the teacher's access or to consider making the blog public. Thus, whether or not the technical issues were distinctly blog-centred or due to poor generic ICT skills, providing assistance with these issues was undoubtedly a necessary aspect of the integration procedure.

Another practical element of this developing teacher role included administrative duties such as calendar keeping and electronic content management. Frequent reminders had to be sent throughout the semester, underlining the upcoming completion dates of the learners' blogs as well as the submission of their essay based on the L2 blogging experience. Again, this was largely because of the limited contact hours which the teacher had with this particular group of learners. More importantly, managing this load of electronic content highlights another aspect of the process which emerged as a major consideration to be factored into the teacher's time management. Creating an electronic database of blog addresses was a basic requirement for this type of class, particularly as a means to keep up to date with students who sometimes deleted their original blogs and restarted using a new blog address. More crucially, given that the submission date was at the end of semester, the teacher's administrative function had to adapt quickly to any changes communicated by the students in relation to their blog spaces. Sometimes this type of action was due to the individual not producing the required type of L2-focused content. At other times this was due to a preference for a different blog hosting site for example Wordpress.com instead of Blogger.com. To complement both technical support and administrative functions, adopting the informal role of student learning advisor was another aspect of this process. This was particularly the case at the beginning of semester when many students sought reassurance as they began blogging. Thus, we had many messages from students expressing their inexperience and understandably seeking support at this early stage of the task.

The second category of the teacher's role - 'pedagogical activities' - was dictated to a lesser extent by specific student requests and depended largely on the teacher intervening at different points after the initial three week formal teaching period. Thus, the examples here are more descriptive in nature and detail the general tasks which emerged in this context. In comparison to the time-consuming administrative duties, these particular actions were at the discretion of the teacher and were not as demanding in terms of the overall workload. The following are two typical examples of these activities:

- For those of you now considering your blog essay (20\%) I have recently added to the resources section a research article that I wrote with two colleagues

- Just to confirm the deadline: please submit the essay based upon your blog writings to me in soft copy by email and hard copy in my pigeonhole in the Dept., before the end of Week 13 .

Addressing the issue of task encouragement and reinforcement, it was decided to email the group at different points of the semester to remind students of the aims of the blog and accompanying essay as well as to reinforce the particular submission dates. Additionally, the teacher also posted relevant reading material on the university VLE at different points of the semester dealing with issues related to blogging and learning. This action also served as an important reminder to students to maintain an academic focus when working on their language learning blogs. Consequently, the VLE did emerge as a vital support system for this course due to the limited contact 
hours for this subject area. Hence, its integration with the pedagogical activities of the teacher provided a valuable communication network with this group of students. Additionally, the global integration context was incorporated into the teacher's action research agenda, taking note of various issues underlined by the students and earmarking areas for development and change for future classes taking this course.

In order to understand this academic environment fully, the following section of this paper shall now expand on the emerging student learning environment and considers how this shapes the integration of blogs within this distinct language learning context.

\section{The student learning environment: Creating an appropriate learning experience}

Up to this point we have outlined the important activities of the teacher with regard to designing the blogging assignment while remaining mindful of timetabling restraints and the recognised learning outcomes of the established course. Moreover, the activities outlined previously in Figure 3 represent the importance of implementing a support system which facilitates the learners' needs during this writing exercise. Whilst acknowledging the important efforts by the teacher to create a meaningful and effective blog integration context, we shall now turn to highlighting the typical reactions as outlined by the students engaged in this specific task. Data from this particular section of the paper has been collated via the learners' blog essays. As such, the reported reactions by the students at the completion of the task are helpful for understanding the impact of the exercise from their own particular point of view. Figure 4 summarises the main features in this learning environment.

As previously mentioned, the second year students at the commencement of this module had no previous experience using blogs in their learning, even though every student had some form of recreational web presence on a social networking site. The distinct expressivist and personalised approach in this module was also a new departure for this group as these participants had been previously accustomed to more traditional, paper-based teaching methods. These particular features noted at the start of the semester are described in Figure 4 as 'existing ICT skills' and 'existing language learning strategies' and as such mark the starting point for acquiring proficiency in other areas. Examples as reported by students include the following:

- As a self-confessed technophobe, the prospect of being able to use and understand technology in a way that was going to help me learn what I love learning most, was a rather exciting prospect.

- I had no experience of blog writing and so had no real idea of how to go about it. Eventually, I pulled myself together and wrote a small entry.

- Reflective learning was not straight forward or easy for me. Not having 'consciously' reflected before, it was hard to know how it should be done and what should be written in the blog.

What is significant here is to acknowledge the importance for the learners to come to terms with the demands of the assignment and to work through these issues during the course of the semester. Understandably, many students were to some degree apprehensive when faced with the prospect of this exercise. For some, the fear of the unknown emerged as an influential factor at the start of the blogging activity, brought about in certain cases by the potentially public nature of the blog space and the enforced expressivist approach. The fact that students may experience this negative 


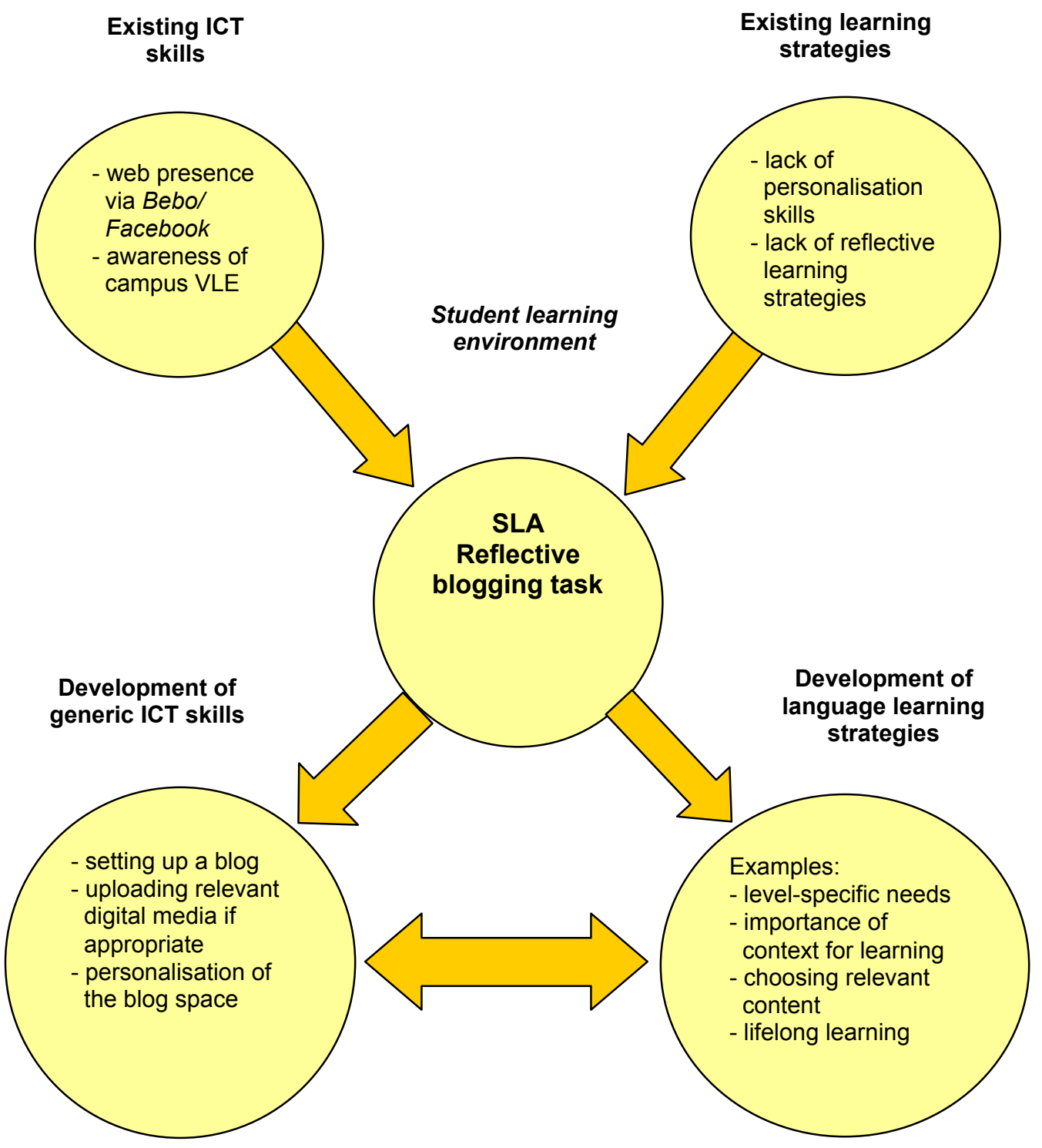

Figure 4: Description of student activities

reaction emphasises firstly the importance of the mandatory nature of the integration exercise - which ensures that they at least attempt the task - and secondly validates the need to offer guidance and encouragement. The design of the assignment, as discussed in the previous section, had to be flexible enough to adhere to the established aims of the Language and Technology module as well as allowing students to reflect upon their personal experiences and attitudes as L2 bloggers. Interestingly, some learners revealed that maintaining the balance between creativity and the required notion of frequent postings was a 'struggle' at times with one student even 'resenting' the mandatory rules of the task. However, it was important that the teacher could see the 
frequent postings on a chronological basis ensuring that at least a basic attempt was made to integrate the blog for these purposes.

The development of 'generic ICT skills' and 'personalised language learning strategies' is thus highlighted in Figure 4 as being representative of these objectives within the general learning context. It was intended by and large that the 12 week blogging experience would give the learners the necessary time to develop these particular ICT skills relative to the task. The basic mechanics of blogging, namely setting up the account and personalising it in terms of design and digital content, were regarded as tangible learning outcomes for the students involved. Thus, it is understandable that the relationship between the student and the teacher was recognised as a vital component as learners needed to feel free to approach with any relevant questions, no matter how basic the subject matter. The 'development of language learning strategies', as outlined here in Figure 4, relates directly to the mandatory, self-reflective approach which learners were obliged to take and as expected produced a wide variety of reactions unique to each student. This non-prescriptive style was thus integral to helping learners to establish their own assessment of their foreign language acquisition and ICT use. Indeed, this common thread served to contextualise the wide range of learner reflections. Interestingly, a number of students, for fear of straying from this context, referred frequently to making a conscious effort to blog L2 based content throughout the semester in order to maintain focus on the topic at hand. A brief sample of patterns which emerged from the data included the following:

- Embracing the wider blogging community to look for content

- Revealing a preference for traditional writing tools

- Recognition of progression in terms of one's learning through self monitoring via the blog

- Shift from recreational to academic contexts

The key feature of this kind of expressivist writing was for students to take responsibility for their learning and to include some form of accountability in this process. Many of these comments were quite positive in nature detailing for example the discovery of other helpful blogs or indeed recognising progress in terms of content output. However, this style of writing also facilitated students to recount negative reactions to using the blog tool and allowed them the opportunity to disregard ICT integration if it did not work for them personally. Thus, some students revealed that they felt more comfortable working within the more traditional pen and paper environment, while others critiqued openly the blogging task itself, stating it was difficult to fit into their schedule. Indeed, one student commented that the blogging task was a 'waste of time' as they only wrote it because it was mandatory.

As such, this emerging trend, which we have termed elsewhere 'negative integration' (Hourigan \& Murray, 2006:313), is simply a natural progression of the student's growing awareness of their needs over this three month period. The main idea was to make learners aware of L2 blogging as a potentially helpful practice for their foreign language acquisition and to ensure that exposure to this task could be helpful for making future choices with regard to their studies. Hence having successfully completed this integration project, it was intended that students be more knowledgeable about their own particular learning styles and could potentially draw on this experience during their learning careers. The most crucial aspect of this process is guiding the initial inexperience of the learners from novice integrators to 
increasingly confidant and informed learners. This aspect shall be developed further in the final section of this paper.

\section{Discussion and current conclusions}

After considering this wide examination of L2 blogging, it is clear that this process presents a number of factors which teachers should consider, ideally from the very outset. Evidently, integrating this type of task into the language classroom is not a straightforward issue and thus requires a great deal of groundwork beforehand in order to validate its inclusion in any type of academic course. For our purposes, successful integration was defined as establishing a realistic timeframe for students to assess and exploit the tool as part of their activities as evaluators of technology for language learning purposes. Additionally, we wanted to emphasise in this course that using technology appropriately requires a certain degree of reflective and interpretative skills which students may not necessarily use in their daily consumption of Web 2.0 media.

One important caveat for any teacher considering using blogs in their teaching is the increased administrative load associated with the nature of this task. Consequently, the decision to implement such an exercise should not be taken lightly as learners will undoubtedly require some form of support over the course of the semester, be it either small scale technical and/or learner support. The reality of providing adequate integration guidance requires that the teacher monitor the class blogs from the beginning of semester, to make sure at least that learners are set up on their individual blog spaces. The demands of this role can vary depending on the student variables, but it is advisable that strategies to manage the administrative load are defined and set in place early on. What is important to ensure here is that students can embrace the creative component of the reflective blogging exercise without being overly weighed down by technical or affective integration issues.

In a sense, the teacher should ideally provide a structured and dependable guidance framework (as represented in Figure 5) which learners can access in times of self doubt or difficulty. This is particularly relevant as the bottom up exploitation of e-learning at third level makes it difficult to standardise student ICT skills for educational purposes. As pedagogical approaches depend on the preferred style of the individual teacher, there is no guarantee that learners can build on particular ICT skills from one semester to the next. Indeed the student cohort may be so diverse in its makeup that the teacher should typically expect to receive requests from some learners seeking clarification on some basic issues, e.g. attaching documents for uploading digital content.

When speaking of secondary level students, Prensky declares: "Our students' strengths lie in their ability to quickly master, use and apply technology, and in their fearlessness to try new things" (2007:46). In addition to Kennedy et al (2008), MacLean and Elwood (2009) also reported problematic variables (proficiency with technologies, tradition, willingness to use technology and gender) with so-called digital natives, concluding: "Use of the term 'Digital Native' should not be used as a blanket term for an entire generation". Indeed, with our Third Level students, such a term would be misleading. Granted that they do belong to the "Digital Native" generation (Prensky, 2007:40) through their extended and quite fearless (and sometimes reckless) use of Web 2.0 tools, yet as we have shown in this paper, many of our students still require explicit direction and validation in the writing of their own academic blogs. 


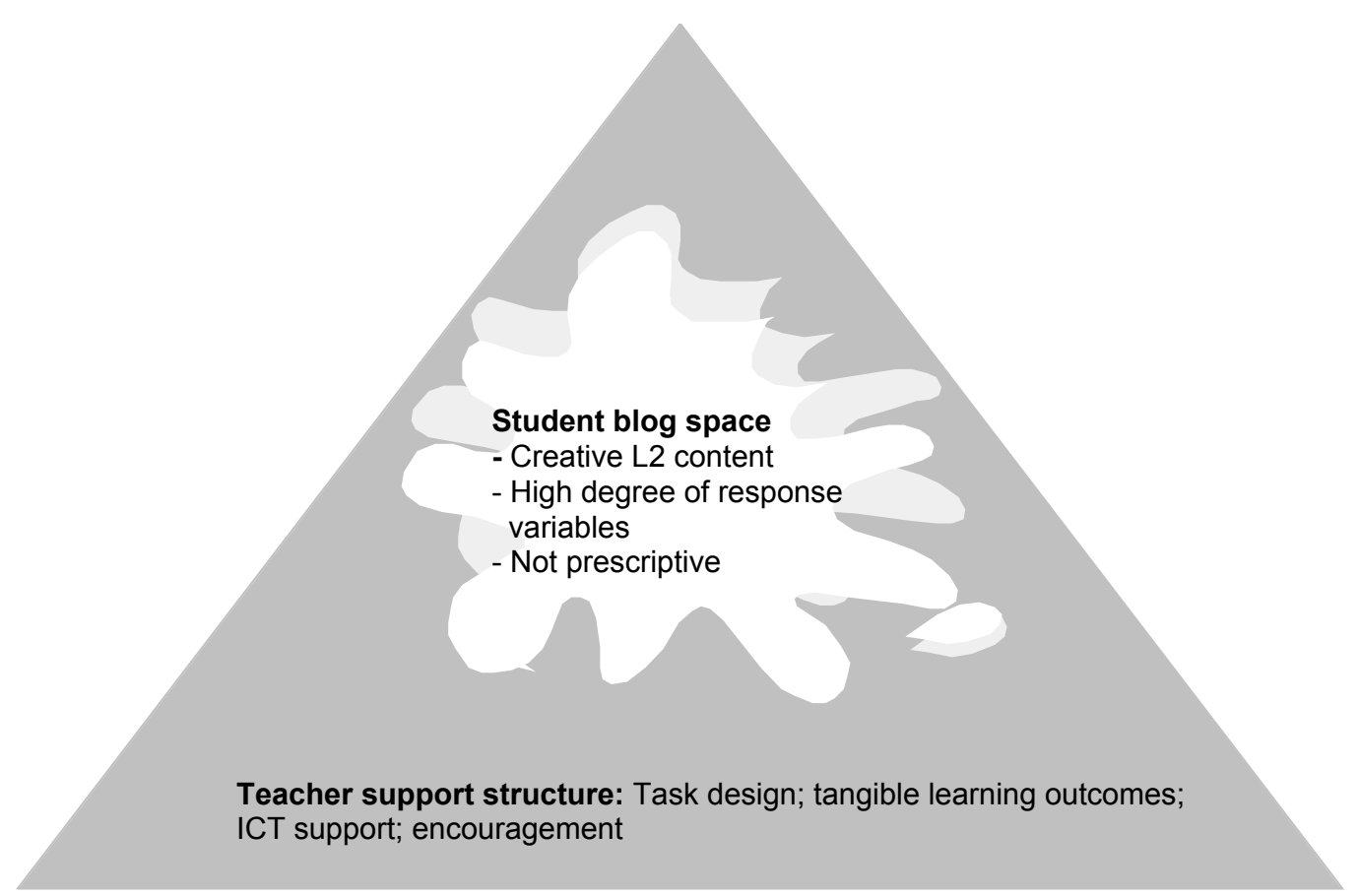

Figure 5: Representation of the blog integration structure

When implementing reflective blogging practices within a distinct pedagogical environment, the most important aspect of the process is in directing the initial inexperience of the learners from neophyte integrators to increasingly confident and informed learners through a learning scaffold, as depicted in Figure 5. There may be some student negativity due to the mandatory nature of the blogging tasks. However, there is a widespread recognition amongst students that the objectives and the learning outcomes are valuable for their present and future multimodal learning needs.

\section{References}

Alexander, B. (2006). Web 2.0 A new wave of innovation for teaching and learning? EDUCAUSE Review, March/April, 33-44. http:/ / www.educause.edu/EDUCAUSE+Review/EDUCAUSE ReviewMagazineVolume41/Web20ANewWaveofInnovationforTe/ 158042

Alm, A. (2009). Blogs as protected spaces for language learners. In Same places, different spaces. Proceedings ascilite Auckland 2009.

http:/ / www.ascilite.org.au/conferences/auckland09/procs/alm.pdf

Alt, C., Astrachan, O., Forbes, J., Lucic, R. \& Rodger, S. (2006). Social networks generate interest in computer science. SIGCSE'06, Houston, Texas, USA. [verified 30 Mar 2010] http: / / www.cs.duke.edu/ forbes/ papers/ sigcse2006.pdf

Butler, J. C. (1998). The Internet - a catalyst for change. Computers \& Geosciences, 24(7), 617-621.

Carney, N. (2009). Blogging in foreign language education. In M. Thomas (Ed), Handbook of research on Web 2.0 and second language learning. IGI Global, 292-312. 
Chinnery, G. M. (2006). Going to the MALL: Mobile assisted language learning. Language Learning $\mathcal{E}$ Technology, 10(1), 9-16. http: / /llt.msu.edu/vol10num1/emerging/default.html

Cochrane, T. \& Bateman, R. (2010). Smartphones give you wings: Pedagogical affordances of mobile Web 2.0. Australasian Journal of Educational Technology, 26(1), 1-14. http:/ / www.ascilite.org.au/ajet/ajet26/cochrane.html

Downes, S. (2004). Educational blogging. EDUCAUSE Review, September/October, 14-26. http: / / net.educause.edu/ir/library/pdf/ERM0450.pdf

Duber, J. (2002). Mad blogs and English(men). TESL-EJ, 6(2). [verified 30 Mar 2010] http: / / www.cc.kyoto-su.ac.jp/information/tesl-ej/ ej22/int.html

Duber's media blog (Duber, 2008). http: / / duber.com/mediablog/content.html

Ducate, L. \& Lomicka, L. (2005). Exploring the blogosphere: Uses of weblogs in the foreign language classroom. Foreign Language Annals, 38(3), 410-421.

Elgort, I., Smith, A. G., \& Toland, J. (2008). Is wiki an effective platform for group course work? Australasian Journal of Educational Technology, 24(2), 195-210. http:/ / www.ascilite.org.au/ajet/ajet24/elgort.html

Farmer, B., Yue, A. \& Brooks, C. (2008). Using blogging for higher order learning in large cohort university teaching: A case study. Australasian Journal of Educational Technology, 24(2), 123136. http:/ / www.ascilite.org.au/ajet/ ajet24/ farmer.html

Ford, P. (2007). Reflections on the effective use of blogs in the classroom. In M. Camilleri, P. Ford, H. Leja \& V. Sollars (Eds), Blogs: Web journal in language education. Council of Europe, Strasbourg, 7-12. [verified 30 Mar 2010; 5.0 MB] http: / / www.ecml.at/documents /D1_Blogs_E_web.pdf

Godwin-Jones, R. (2003). Blogs and wikis: Environments for on-line collaboration. Language Learning \& Technology, 7(2), 12-16. http: / /ltt.msu.edu/vol7num2/ emerging/default.html

Godwin-Jones, R. (2005). Messaging, gaming, peer-to-peer sharing:Language learning strategies \& tools for the millennial generation. Language Learning and Technology, 9(1), 17-22. http: / /llt.msu.edu/vol9num1/emerging/default.html

Heilesen, S. \& Josephsen, J. (2007). E-learning between augmentation and disruption? Paper presented at $C A L^{\prime} 07$, Development Disruption $\mathcal{E}$ Debate, Dublin, March 2007. [also in Computers $\mathcal{E}$ Education, 50(2), 525-534, 2008]

Hendron, J. G. (2003). Educators as content publishers. The VSTE Journal, 17(3), 2-6.

Hill, B. (2006). Blogging for dummies. Wiley Publishing Inc. Indiana.

Hourigan, T. \& Murray, L. (2006). Mapping successful language learning approaches in the adaptation of generic software. Computer Assisted Language Learning, 19 (4 and 5), 301-316.

Hsu, C-H. \& Lin., J. C-C. (2008). Acceptance of blog usage: The roles of technology acceptance, social influence and knowledge sharing motivation. Information $\mathcal{E}$ Management, 45, 65-74.

Hubbard, P. (1996). Elements of CALL methodology: Development, evaluation and implementation. In M. Pennington (Ed), The power of CALL. Texas: Athelston (pp. 15-32).

Kennedy, G.E., Judd, T.S., Churchward, A., Gray, K. \& Krause, K-L (2008). First year students' experiences with technology: Are they really digital natives? Australasian Journal of Educational Technology, 24(1), 108-122. http: / / www.ascilite.org.au/ajet/ajet24/ kennedy.html 
Kern, R. (2006). Perspectives on technology in learning and teaching languages. TESOL Quarterly, 40(1), 183-210.

Kukulska-Hulme, A. \& Shield, L. (2008). An overview of mobile assisted language learning: From content delivery to supported collaboration and interaction. ReCALL, 20(3: Special issue on mobile assisted language learning), 19-31.

Leja, H. (2007). Improving writing skills in foreign language classes. In M. Camilleri, P. Ford, H. Leja \& V. Sollars (Eds), Blogs: Web journal in language education. Council of Europe, Strasbourg, 27-34. [verified 30 Mar 2010; 5.0 MB] http: / / www.ecml.at/documents /D1_Blogs_E_web.pdf

Lockyer, L. \& Patterson, J. (2008). Integrating social networking technologies in education: a case study of a formal learning environment. Paper presented at the Eighth IEEE International Conference on Advanced Learning Technologies, Santander, Spain. [verified 30 Mar 2010] http: / / ro.uow.edu.au/edupapers / 73 /

Lonn, S. \& Teasley, S. D. (2009). Podcasting in higher education: What are the implications for teaching and learning? The Internet and Higher Education, 12, 88-92.

MacLean, G. R. \& Elwood, J. A. (2009). Digital natives, learner perceptions and the use of ICT. In M. Thomas (Ed), Handbook of research on Web 2.0 and second language learning. IGI Global, 156179.

Murray, L. \& Hourigan, T. (2005). Identifying roles for blogs in SLA. Paper presented at UNTELE 2005: Input, Interaction, Feedback, Evaluation Second Language Acquisition and Multimedia Environments, l'Université de Technologie de Compiègne, France.

Murray, L. \& Hourigan, T. (2007). Blog writing integration for academic language learning purposes: towards an assessment framework. Iberica, 14, 9-32. [verified 30 Mar 2010] http:// www.aelfe.org/documents/14-02_murray.pdf

Murray, L. \& Hourigan, T. (2008). Blogs for specific purposes: Expressivist or socio-cognitivist approach? ReCALL, 20(1), 83-98.

Paraskeva, F., Mysirlaki, S. \& Papagianni, A. (2010). Multiplayer online games as educational tools: Facing new challenges in learning. Computers \& Education, 54, 498-505.

Prensky, M. (2001). Digital natives, digital immigrants. On the Horizon, 9(5). [verified 30 Mar 2010] http:/ / pre2005.flexiblelearning.net.au/projects / resources/Digital_Natives_Digital_Immigrants.pdf

Prensky, M. (2007). How to teach with technology: Keeping both teachers and students comfortable in an era of exponential change. Emerging Technologies for Learning, 2, 39-47. BECTa, UK. [verified 30 Mar 2010] http: / / partners.becta.org.uk/ uploaddir/downloads/page_documents/research/emerging_technologies07_chapter4.pdf

Raith, T. (2009). The use of weblogs in language education. In M. Thomas (Ed), Handbook of research on Web 2.0 and second language learning. IGI Global, 274-291.

Richardson, W. (2006). Blogs, wikis, podcasts, and other powerful web tools for classrooms. Thousand Oaks, CA: Corwin Press.

Rourke, A. J. \& Coleman, K. (2009). An emancipating space: Reflective and collaborative blogging. In Same places, different spaces. Proceedings ascilite Auckland 2009. http:/ / www.ascilite.org.au/conferences/ auckland09/procs/rourke.pdf

Sollars, V. (2007). Writing experiences in a second/foreign language classroom: From theory to practice. In M. Camilleri, P. Ford, H. Leja \& V. Sollars (Eds.), Blogs: Web journal in language education. Council of Europe, Strasbourg, 15-24. 
Strampel, K. \& Oliver, R. (2008). We've thrown away the pens, but are they learning? Using blogs in higher education. In Hello! Where are you in the landscape of educational technology? Proceedings ascilite Melbourne 2008.

http: / / www.ascilite.org.au/conferences/melbourne08/procs/strampel.pdf

Vie, S. (2008). Digital divide 2.0: “Generation $M$ " and online social networking sites in the composition classroom. Computers and Composition, 25, 9-23.

Walinski, J. (2005). Monitoring E-learners' Feedback with Blogs. In J. Walinksi, K. Kredens \& J. Gozdz-Roszkowski, (Eds), Corpora and ICT in language studies. Proceedings of PALC 2005. Peter Lang, Frankfurt, 431-443.

Wikipedia (2008). Definition of a blog. [viewed 27 Jul 2008, verified 30 Mar 2010] http: / / en.wikipedia.org/wiki/Blog

Walls, S. M., Kucsera, J. V., Walker, J. D., Acee, T. W., McVaugh, N. K. \& Robinson, D. H. (2010). Podcasting in education: Are students as ready and eager as we think they are? Computers $\mathcal{E}$ Education, 54, 371-378.

Will, R. (2005). Blogs in education. [viewed 9 Jul 2009]. http:/ / www.weblogg-ed.com/

Xie, Y., Ke, F. \& Sharma, P. (2008). The effect of peer feedback for blogging on college students' reflective learning processes. The Internet and Higher Education, 11, 18-25.

Zorko, V. (2009). Factors affecting the way students collaborate in a wiki for English language learning. Australasian Journal of Educational Technology, 25(5), 645-665. http:/ / www.ascilite.org.au/ajet/ajet25/zorko.html

Tríona Hourigan (corresponding author) is the ISSP Research Scholar, School of Languages, Literature, Culture, and Communication, Institute for the Study of Knowledge in Society, University of Limerick, Plassey, County Limerick, Ireland. Email: triona.hourigan@ul.ie

Liam Murray, School of Languages, Literature, Culture and Communication, University of Limerick, Plassey, County Limerick, Ireland. Email: liam.murray@ul.ie 